\title{
The Truth of Cultural Diplomacy
}

\author{
Riski Muhamad Baskoro \\ International Relations Study Program, Faculty of Humanities \\ President University \\ riskibaskoro@president.ac.id
}

\begin{abstract}
ABSTRAK
Semenjak United States Information Agency (USIA) tidak lagi aktif dalam menjalankan diplomasi budaya pasca perang dingin, konsep diplomasi budaya mengalami masa krisis dalam konteks studi Hubungan Internasional. Selama satu dekade, diplomasi budaya terpinggirkan dan dianggap ketinggalan zaman pada studi Hubungan Internasional. Hingga akhirnya di awal tahun 2000-an, diplomasi budaya seperti hidup kembali dan dioperasionalisasikan baik dalam praktik maupun teori. Semenjak saat itu, diplomasi budaya kembali pada jalurnya. Wacana diplomasi budaya dalam studi Hubungan Internasional telah berkembang untuk mendapatkan kegiatan yang lebih spesifik. Tulisan ini adalah comprehensive literature study yang mengevaluasi atau menguji validitas teori dari berbagai referensi dengan tujuan memahami diplomasi budaya secara lebih holistik. Hasil penelitian ini menunjukkan adanya perdebatan dan tidak adanya konsensus pada beberapa aspek diplomasi budaya dan menghasilkan ketidakjelasan pada akhirnya. Studi ini juga menunjukkan dikotomi antara diplomasi budaya dan pendekatan lainnya.
\end{abstract}

Kata Kunci: Diplomasi Kebudayaan, Soft Power, Hubungan Internasional

\begin{abstract}
Since the United States Information Agency (USIA) is no longer active in operating cultural diplomacy in the post-cold war, the concept of cultural diplomacy has experienced a time of crisis in the context of International Relations studies. For a decade, cultural diplomacy was marginalized and considered obsolete until finally, in the early 2000s, cultural diplomacy was revived and activated both in practice and theory. Since then, cultural diplomacy has returned to its path. The discourse of cultural diplomacy in International Relations studies has developed to gain more specific activities. This is comprehensive literature review which evaluates or examines the validity of the theory from various references with the aim of understanding cultural diplomacy in a more holistic way. The results of this study indicate a debate and a lack of consensus on several aspects of cultural diplomacy and bringing much unclear explanation. This study also shows a dichotomy between cultural diplomacy and other approaches.
\end{abstract}

Keynotes: Cultural Diplomacy, Soft Power, International Relations 


\section{Cultural Diplomacy, A Forgotten Treasure in the late of $20^{\text {th }}$ century}

To begin with, Mark (2009: 1-44) points out through his research that cultural diplomacy does not get much attention from International Relations scholars in the late 20th Century. The statement gets some endorsement from various International Relations scholars, such as Schneider (2007:148-151) and Ma (2014: 394-397). Those scholars have the same similarities to Mark's (2009: 1-44) thought, arguing that cultural diplomacy is something unimportant in the end 1990 onwards. Cultural diplomacy is not a main course or a tool to be used in diplomacy activities, it is outdated and its popularity is shrinking in the end of the Cold War.

It can happen for some reasons when Mark (2009: 1-7) believes in some aspects. Firstly, neither diplomats nor politicians do really rely on the practice of cultural diplomacy where culture plays as the main aspect in the practice of diplomacy. The government seems to be more serious on formal and 'conventional' diplomacy which communications between states are dominated and orchestrated among officials of government or in other word, best known as first track diplomacy. The non-state actors, like independent institutions, private groups which are supposed to be supported by the government to operate the system of cultural diplomacy seems not to be reflected on as a "serious" part of negotiation among states.

Secondly, as it is discussed by Mark (2009:1-7), for diplomacy using culture captivate a minimum attention from International Relations Scholars since the urgency given to the concept of cultural diplomacy is too stunted and even inferior due to struggling and failures in shaping the period of term impact of cultural diplomacy towards the changes of target audience behavior. However, practically some measurement indicators could be utilized to identify the success of cultural diplomacy through events and activities. For examples by identifying and counting the number of audiences visiting an event, exploring feedback in a ballet show and the existing media coverage in an opening of a new road or researching audience comments. Nevertheless, cultural diplomacy endorsement from high states officials as related parties in setting up budget for culture and diplomacy has been shrinking due to the absence of fact and evidence displaying the real or direct concussion of cultural diplomacy on audiences in a time given.

Third, Mark (2009:1-7) argues that lack of attention from International Relations academicians over cultural diplomacy may be because of the minimum of clarity, exploration and elaboration about what is precise of the activities in cultural diplomacy entails. Tons of definitions emerge about what cultural diplomacy itself. 
It lies with two (2) terms and divided into culture and diplomacy. It seems, the terminology of culture creates more problems to gain the precise details in the clarity of cultural diplomacy' definition (Ma 2014: 394-397). In fact, cultural diplomacy was one of the most sought-after approaches during the era of cold war, where the United States of America was recorded several times using a cultural approach in making contact with other countries to ensure that its influence, democracy and liberalism, was spread in an organized manner through the practice of Jazz Ambassador. Since the cold war diminished until the end of the 20th century, cultural diplomacy is a terminology left by many International Relations academicians, however, it was successfully revived in the early 21 st century.

This study aims to determine the characteristics of cultural diplomacy, as it can be seen from all aspects and activities resemble cultural diplomacy. This research also seeks to explain the actors, the objectives of cultural diplomacy and to explain a few things about the development of cultural diplomacy as well as providing potencies and abilities of the concept of cultural diplomacy. This study uses qualitative methods, with observing several journals and documents related to cultural diplomacy as research instruments.

\section{A Little Hope Inside the Pandora Box}

From all the way and any kinds of confusion in order to identify cultural diplomacy as well as Mark's ideas that mentioned cultural diplomacy would be extinct, there is a little hope to keep cultural diplomacy existing in the study of International Relations. I try to put some efforts in order to find the truth by separating the terminology of culture from diplomacy as it is believed the concept of cultural diplomacy has some hopes. First, I bring culture to be examined. Kidd (2002) claims that culture as 'the way of life of a group of people'. The term of culture, in fact, has a multidimension of interpretation along with massive wide-ranging to understand and it is also difficult to describe. It is clear, there is no obvious agreement over cultural meaning. In a surface understanding, a terminology of 'culture' has been realized and being discussed among Anthropologists, as it is a theme which focuses on the discipline of mankind and its culture (Milner and Browitt, 2002). Even though there is no clear agreement over cultural definition, Kidd (2002) defines it in an easy way.

The study of Anthropology concerns on the cultural role, the setting surrounding the culture, and how culture is learnt. Preferring to explore and identify themselves or others and it becomes identities. In addition, they have an objective to elaborate the group of people through the mindset of those who are living on it. Scholars believe culture is made by a group of communities who are living in a place where traditions, norms and beliefs exist (Kidd 2002). 
Griffin (2009: 264-269) argues that culture is the terminology that is tough to express; culture is not only mentioned about arts, dance, music, exchange students abroad, and photography, it must be what mankind does when they are cognizant of people's imagination. Griffin (2009: 266-269) continues to offer a model on how culture applies in community. Take a look when people smile with others (sense of humour), how they interpret, understand and practice in their daily life, how they think about something. Thus, culture does not only discuss small-scale and limitations but also broad dimensions which make it complicated to know culture deeper. In line with Griffin (2009: 266-269) perspective in examining culture, Mark (2009: 5-8) also argues the same voice as Griffin. Conventionally, culture is associated with literature (language), dance, visual arts, theatre and any other prime examples in the form of cultures. Currently, national identities are shaped as culture plays a vital role in it. Meanwhile, if we take a look to UNESCO universal definition of Culture, in Memis (2009: 298), it is can be described below;

\begin{abstract}
"the whole complex of distinctive spiritual, material, intellectual and emotional features that characterize a society or social group, it includes not only arts and letters but also modes of lifes, the fundamental rights of human beings, value systems, traditions and beliefs"
\end{abstract}

In spite of the complexities of its descriptions on culture, it might be effective on cultural diplomacy as well. Where cultural diplomacy as the terminology has disoriented approach to other activities or methods which are deliberated similarly with. Mellisen (2007: 16-23) claims cultural diplomacy is probably not the same as propaganda. Instead, Mutsaka (2013: 6) and Leonard (2002) state that cultural diplomacy is a slice of public diplomacy yet with dearth of elaboration on how cultural diplomacy can be a subset of public diplomacy. Various scholars such as Schneider (2009) Mark (2009) and Croft (2013) address that cultural diplomacy is a distinct practice in diplomacy. Hence, this part of writing is too complex and confusing because there are so many various explanations on cultural diplomacy. But, if we take a look again, despite the chaotic explanation of cultural diplomacy, there is a small hope to assist cultural diplomacy to still exist in the realm of International Relations studies. The concept resists dimming like the box of Pandora in a Greek mythology where amid chaos, drama and problematics in the history of mankind, there is still a hope of joy. For the next discussion, this paper is going to explain more the relationships and discuss the exact definition of cultural diplomacy. 


\section{Milton Cummings and The Revival of Cultural Diplomacy}

As I mentioned above in the previous part of this writing, cultural diplomacy has some meanings and it might depend on the school of thought of scholars and it can make different points of view to see cultural diplomacy. But one thing that should be understood is when the conceptual framework of cultural diplomacy develops and continues to grow by various of the US scholars. Specifically, Cultural diplomacy has been defined well by American scholars as the concept emerges and is known for the first time in the United States. It is defined as:

"the exchange of ideas, information, art and other aspects of culture among nations and their peoples to foster mutual understanding" (Cummings 2003)

Definition above also could be continued as what nations do to tell stories and introduce themselves to the world. Based on my literature research, the definition made by Cummings is significant and legendary in order to influence many American scholars that bring interest in Cummings' definition about cultural diplomacy. One of them is Schneider (2009) who has confidence in Cummings invention on the term of cultural diplomacy. Schneider (2009) even believes that Cummings found the greatest devising of all time about culture and diplomacy talks about. Cummings definition can be considered as a "passcode" to enrich knowledge on cultural diplomacy. Currently, Cumming's descriptions on cultural diplomacy have been utilized by many scholars. Thus, this chapter discusses the revival of cultural diplomacy started with Milton Cummings impacts.

In addition, not only Schneider that was lining her thoughts to Milton Cummings, another American scholar like Finn (2003: 15-20) also has a similar point of view in looking at culture and diplomacy. On the other hand, Finn (2003: 15-20) compliments that cultural diplomacy also takes a part to 'win the hearts and minds' of the target audiences. Finn also believes, in cultural diplomacy, there is continually a linking part between cultural diplomacy policies conducted by the state to occupy foreign audiences in order to win over ideological enemies, as the US did in a post-World War II and it is also related to national security. Based on Finn (2003: 15-20) research, cultural diplomacy could be used to promote democracy as code of conduct to other countries. It is spread out through music, food, films, education and arts or any other cultural elements. Hence, this can bring a positive effect to political stability and national security (even though it needs more research to get an exact answer) for states which practice cultural diplomacy for a period of time; it is beneficial to maintain their existence and their influence (Monten 2005). Starting from Cummings' view toward cultural diplomacy in the year of 2003, the discourse of the concept continues to grow and develop. 
Cummings revives cultural diplomacy as a concept in the International Relations study program after apparent death for a decade.

In accordance with Cummings (2003), Finn (2003: 15-20) and Schneider (2009), another scholar such as Stamatoudi (2009: 116-120) claims cultural diplomacy is used as a negotiating media for some issues. Culture may be the solitary vehicle that lets nation states to work closer in partnership and fruitfully to share communal interest. In fact, one of the prime example is written well by Finn's (2003: 15-20) research about how American foreign policy through culture effects in the Muslim countries where implementation of diplomacy by culture is clear to influence young generations to admire the American pop culture. Yet, it is a real luckless when neither Finn (2003: 15-20) and Stamatoudi (2009: 116-120) fail to explain more argumentative reason if there are any relationships within cultural diplomacy to 'win the hearts and minds' of people as well as to transform their behaviors, and also for countries to collaborate closer to share mutual interest with target group. It seems the celebration of cultural diplomacy becomes unfruitful as it has no reasonable description on the linkage within.

However, the deficiency of enlightenment given by Stamatoudi (2009: 116120) and Finn (2003: 15-20) might be filled by Schneider (2007: 147-168) arguments that the cultural diplomacy activities can be formed and seen from Jazz concert music (Jazz Ambassador or Jazz diplomacy) that can influence the audience preference. The music of Jazz has a clear message about the sense of liberty, American values, freedom of expressions, equalities and also democracy to hamper the ideology of communism during the Cold War through Jazz music. According to Gienow-Hecht (2010: 3-13) The United States' mission to contend against communism over cultural diplomacy was noticeably successful as Jazz ambassadors can work closely to the target audience.

According to Mark (2009) cultural diplomacy works as the engagement of state's culture and heritage in assisting its foreign policy goals or diplomacy. On the other hand, academicians such as Cummings (2003) and Schneider (2007: 147168), emphasis on culture exchange and mutual understanding. It can be seen that while Mark (2009: 7-8) puts concern on the cultural aspects that assist the foreign policies of the state, both Schneider and Cummings simply put mutual understanding as the foremost objective of cultural diplomacy. It is exactly the point of difference between those scholars. But, one thing that they believe together and it becomes a consensus within many scholars is when they explain about the emergence of cultural diplomacy as Mark (2009: 7-8) explains that cultural diplomacy begins to prosper in the early of $21^{\text {st }}$ century where the emergence countries start to establish cultural diplomacy practice for their own, as supporters, to achieve the objective of its foreign policy. Mark (2009) continues his 
opinion that cultural diplomacy has the great potential to become a powerful media for improving a country's reputation and image and its relations with others.

Furthermore, Warsito and Kartikasari (2007) outline it as an effort conducted by a state to achieve national interest through dimensions of culture, and mostly using micro methods such as art, education, science, sport, and also propaganda as macro methods. It can be agreed that Warsito and Kartikasari view on cultural diplomacy have similarities to Mark (2009), where they believe the actor of cultural diplomacy is state. On the other hand, Mark (2009) distinguishes propaganda and cultural diplomacy which is acknowledged by Warsito and Kartikasari (2007) as two similar ways of activities. To be added, Schneider also claims cultural diplomacy is a widespread form of diplomacy, the actor not limited to government and high-level officials, but non-state actors also contribute in practices, such as private companies. Schneider claims cultural diplomacy is a dissimilar topic from propaganda or public diplomacy (National University of Singapore, 2012).

Last but not least, is the definition of cultural diplomacy established by the Institute for Cultural Diplomacy (ICD) that sees cultural diplomacy can be orchestrated by privates (non-state actors). Compared to previous analysis on definition on cultural diplomacy that is cited before, ICD incorporates all of the actors of cultural diplomacy into one. ICD argues in many ways that cultural diplomacy improves and develops the technique of diplomacy. Eventually, in the $21^{\text {st }}$ century, there are numerous parties (as many scholars have mentioned earlier) around the world, not only scholars but also practitioners, government officials, politicians and more that can be incorporated into diplomacy.

\section{Cultural Diplomacy as a Soft Power}

Before I continue to see the relationship between cultural diplomacy and soft power, I would like to identify soft power in the first place. If the discourse of International Relations study goes to soft power, then, the only scholar that needs to get lots of appreciation must be Joseph Nye. According to Nye (2004), power is the ability to give impact towards others' behavior to realize certain goals. Nye claims, there are a portion method in order to obtain people or actors want or what they desire. Threats are utilized to make the others fear and this method is used to frighten others to get what the actor wants. Another method uses money in order to persuade others and last but not least become the members to share similar willingness.

In the context of soft power, addressing the outcomes with peaceful relations is much more preferable rather than making any threats or creating conflict. Soft power is a totally different way to the opposing hard power. Hard power relies on 
coercion and forcing others to follow a kind of direction. Soft power is common to be practiced in international politics, where the actors lie not only by state but also non-state actors which enables others to achieve the outcomes they want implicitly or indirectly and somehow the target feels unrealized if they are under control by the activities of cultural diplomacy.

According to Nye (2004), Soft power relies on at least 3 resources:

(1) its culture - in places that appeal to others

(2) its political values - when it grows and spreads at home and abroad

(3) its foreign policies - when others view them as legitimate and containing moral authority.

Based on that matter, it can be concluded culture is fuel to operate the engine of soft power as can be seen in the first resource of soft power. Thus, it could be described as well that cultural diplomacy is a part of soft power as it encompasses cultural elements and does not utilize hard power where military approaches, coercions or threats are prior. Soft power, usually, leads to a state's culture where there are the criteria of political values and foreign policies.

The idea from Nye get so much endorsement by Schneider (2007:147-168), which argues the method of cultural diplomacy is full of enjoyment, more delightful and entertaining than any other practices of conventional diplomacy. In doing cultural diplomacy, states do their own creative expressions and innovations to attract public audiences. Cultural diplomacy is a prominent form of soft power as it works by seducing via elements of culture. In an agreement with Schneider (2007: 147-168), Jang and Paik (2012: 196-202) illustrate; one state needs to boost or enhance their reputation and image, then, how to get that? A state can promote its traditional music, films, culinary, arts, language and more. And usually it has been packed in a tourism program. The result expects a more enjoyable opinion of audiences and make positive credibility. Additionally, Stamatoudi (2009: 116-120) claims that exhibitions like arts, galleries and museums could also be involved in the world of cultural diplomacy and the whole of those activities is believed as part of soft power practice. Griffin (2009: 258-269) says, practically, cultural diplomacy is broad and wide, it can also involve in government programs which are related to culture.

\section{The Core Elements of Cultural Diplomacy: Actors and Objectives}

ICD (2014) shows, in the practices of cultural diplomacy all related parties must cooperate with each other to get involved in the dimension of cultural diplomacy (or applied cultural diplomacy). It encourages all actors either state or nonstate in order to contribute, as it shows in the model of American soft power approach 
where the state and nonstate actors incorporate to implement cultural exchange programs or conveyance delegations (ambassadors to American Jazz musicians) or holding international competitions like sport events. Those illustrations could give impact to audiences understanding on intercultural and interfaith cases and assist encouraging reconciliation in a very exclusive way. Yet, it must be a very long journey in order to achieve reconciliation using the path of diplomacy and culture.

On the other hand, the cultural diplomacy proposed by ICD (2014) is opposed to Mark's (2009:8) point of view. To Mark, the practice of cultural diplomacy only shared and limited to the government as the main or maybe the only actor that played in these practices to achieve the state's interest. Otherwise, all of the practices of diplomacy using the media of culture, cannot be defined as cultural diplomacy, if the actor is not state.

Schneider (2012); Stamatoudi (2009: 116-120); Jang and Paik (2012: 196202); Finn (2003: 15-20), however, be in dispute with Mark (2009: 8) opinion. The rest of the scholars convince, the actor of cultural diplomacy is not limited to the state, it could be anyone, not only the government but also individuals, celebrities, musicians, academicians, chefs, athletes or even vloggers and more.

Furthermore, according to Warsito and Kartikasari (2007), the main purpose of cultural diplomacy is to achieve the state's interest by persuading international audiences or communities to support one foreign policy. Schneider (2009) claims, the form of cultural diplomacy can be varied, it is hired to do culture exchange, two ways of communications, information sharing in order to foster mutual understanding within states. The purpose of this method is loud and clear, which is to bring positive impact for peace in a peaceful way. In a very simple and brilliant way Schneider (2012) explains on the Seminar in Singapore on how cultural diplomacy works;

\footnotetext{
"by the means of attraction, if people look at you and admire you for what you are doing and one in some way to emulate and learn from you. They would try to be like you. They know who you are and the important part is they really like you. It is less likely if there is understanding would occur hostility"
}

Waller's (2009) idea may connect two thoughts between Schneider (2012) and Warsito and Kartikasari (2007) where Waller contends cultural diplomacy is intended to affect target audiences. Then, over the long-term period of time, result is expected the affections which are spread and develop can be utilized as a sort of proper comportment to organize and win support from the target audience. It also attempts to operate cultural dimensions persuading foreigners (audiences) to see 
culture, people, and policies living in the state's in a more positive way. Cultural diplomacy also attempts to promote greater collaboration between countries, furthermore, it works together with the target nation in preventing, mitigating and managing disputes. As the result expected, cultural diplomacy could enhance mutual understanding among states and nations.

However, sometimes, a real ambitious purpose is also embodied in the objective of cultural diplomacy, where according to ICD (2014), the purpose itself is to maintain stability and peace. On the other hand, Mark (2009: 9) claims that cultural diplomacy supposes undertaking an idealistic pathway, as mitigating conflict would take years to come to obtain the result. Mark indicates cultural diplomacy has functional purposes as well such as: improving culture, trade, politics, economics and diplomatic elements of a nation.

Based on the debates on the chapter of core elements of cultural diplomacy, it can be said that actors and the objectives are important. Actors are non state and state, but in my opinion, in the practice of cultural diplomacy, non state actors dominantly practiced the cultural diplomacy, while state actors being supporters for those activities. For objectives of cultural diplomacy, various scholars state the importance of people to people contacts to foster mutual understanding in a peaceful way, as it is already explained in the previous paragraph.

\section{Cultural diplomacy at the Crossroads}

The terminology of cultural diplomacy has been overused and can be considered to overlap with other terminologies and practices of diplomacy in the context of International Relations studies. More specifically, there are several concepts (similar with cultural diplomacy) that are considered or often overlap with the concept of cultural diplomacy, namely; public diplomacy and international cultural relations (ICR). Although many international relations experts have mentioned public diplomacy and its connection to cultural diplomacy, not many scholars have tried to look after the two in a holistic manner. The identification is only in the order, that the two concepts are related to one another. Some suggest, the public diplomacy approach is considered not too much use of cultural elements, however, this brings a lot of questions and doubt, is there any soft power approach that does not use cultural elements? Eventually, public diplomacy and also international cultural relations (ICR) is a soft power approach method, so it is likely that public diplomacy also uses cultural elements in its practice.

Public diplomacy, believed, is only occupied and controlled by the actor of the state, meanwhile cultural diplomacy needs broaden actors, not only state but also non-state. It might be the gap between public diplomacy and cultural diplomacy. 
This statement, obviously, needs more evidence and investigations concerning disparities of public diplomacy and cultural diplomacy. Unclear investigations within many aspects will bring bewilderment within the two. Meanwhile, international cultural relations (ICR) also cannot be present as the synonym of cultural diplomacy because some of the realm of relationships need no government involvement. In this context, the state must be inactive to employ international cultural relations (ICR) or even no need of contribution over foreign policy goals and negotiations orchestrated by the government. Yet, in cultural diplomacy, the state should incorporate together the whole parties involved including the state actor. Actually, both terminologies are completely rigid to differentiate as various programs and actions may be proven as the same. The case is much more complex to define. Nevertheless, Mark (2009: 17-22) attempts to explore how cultural diplomacy operates. At the end, based on Mark analysis, both concepts, eventually, can be interpreted as different. Although Mark is still incapable to explain both terms more explicitly, Mark deserves to be respected, valued and appreciated as he may be the one of very rare numbers of scholars who are able critically perceive the development of cultural diplomacy.

There is also a discourse which states that cultural diplomacy is another word for propaganda (synonym). However, propaganda is actually considered as the state's interest to achieve certain goals by spreading news and facts which are sometimes invalid. Propaganda was widely used during both the world war and the cold war. Meanwhile, cultural diplomacy has unique characteristics in which the actor is like telling a story to the world about his identity. In other words, in communicating with their targets (audiences), actors implementing cultural diplomacy use news and valid facts opposed to propaganda. Cultural diplomacy from its surface looks like 'propaganda' operated by the inclusive government. Yet, the commitment to engage in international audiences altogether with the inherent honesty distinct cultural diplomacy from propaganda. The investigation should be whether propaganda has transformed to cultural diplomacy? Or whether the modern form of propaganda can be called public diplomacy? Investigations and more research must be employed to gather information regarding the dichotomy of propaganda and public diplomacy.

On the other hand, both academicians Leonard (2002) and Melissen (2007: 343) state cultural diplomacy is a subset of public diplomacy because it has the same objectives but uses it in a different approach, while, Mark (2009: 12-13) argues that cultural diplomacy insertion within public diplomacy's realm. It displays how the recent change of cultural diplomacy is executed and cherished. Since decades ago, International Relations scholars have realized cultural diplomacy as an activity directing on cultural dimensions than as a practice associated with public diplomacy in such a way. From this point of view, it indicates there has been recent 
dominance on public diplomacy or even, the government has yet fully reinforced cultural diplomacy as public diplomacy. In line with Mark's way of thinking, Schneider (2009: 260-261) also endorsed that cultural diplomacy often takes part in a cultural space, no matter what it is, if one utilizes cultural aspects in its diplomacy, thus it has, considerably, utilized cultural diplomacy. Honestly, the debates bring nowhere as IR scholars have their own way of thinking in cultural diplomacy, moreover, there is no agreement between scholars regarding the overuse concept of cultural diplomacy. It brings cultural diplomacy to the neverending episodes, that is why cultural diplomacy is stranded at the crossroads.

\section{Conclusion}

Cultural diplomacy is one of the methods that the state has in making contact with others. Cultural diplomacy has great potencies that can be utilized to spread the ideology and identity of a state. Cultural diplomacy, at the first place, did not get much attention from international relations scholars, until Milton Cummings pinned the terminology of cultural diplomacy. Furthermore, it gives impact and influence to many scholars who are focused on cultural diplomacy discourse. Thus, the concept is still prominent in the world of international relations. Cultural diplomacy is believed by scholars as an extension of soft power and it is part of public diplomacy. The actors of cultural diplomacy are numerous, from state actors to non-state actors with the aim of promoting the national interests of a country, peacefully, with the target of the international community. Cultural diplomacy has a little difference with public diplomacy and international cultural relations. 


\section{References}

\section{$\underline{\text { Books }}$}

Croft, C. (2013) 'Dance Returns to American Cultural Diplomacy: The U.S. States Department's 2003 dance residency and its after effects. Congress on Research in Dance. 45 (1) 23-39

Cummings, M.C. (2003) Cultural Diplomacy and the United States Government: A Survey. Washington D.C. : Center for Arts and Culture.

Gienow-Hecht, J. C. E. (2007) 'Introduction: Searching for a Cultural Diplomacy'. In Searching for Cultural Diplomacy. Gienow-Hecht, J. C. E. And Donfried, M.C. New York : Berghahn, 3-13T

Kidd, W. (2002) Culture and Identity. New York: Palgrave.

Leonard, M. (2002) Public Diplomacy. London: The Foreign Policy Centre.

Mellisen, J. (2007) 'Introduction' in The New Public Diplomacy Soft Power in International Relations. Ed. By Mellisen, J. New York : Macmillan, 3-23

Mark, S. (2009) 'A Greater Role of Cultural Diplomacy' Netherlands Institute of International Relations 1 1-44

Milner, A. and Browitt, J. (2002) Contemporary Cultural Theory. 3th edn. London: Routledge

Mutsaka, C. M. (2013) Changing Foreign Public Perceptions Through Culture: Comparative Study of the Cultural Diplomacy of France and China in the Mekong Sub-Region. Published MA Dissertation. London: Webster University.

Nye, J. S. (2004) Power in the Global Information Age. London: Routledge

Nye, J. S. (2004) Soft Power: The Means to Success in the World Politics. The United States

Schneider, C. P. (2007) 'Culture Communicates: US Diplomacy That Works'. In The New Public Diplomacy: Soft Power in International Relations. Ed. By Mellisen, J. New York : Macmillan, 147-164

Waller, J.M. (2009) 'Cultural Diplomacy, Political Influence and Integrated Strategy'. In Strategic Influence: Public Diplomacy, Counterpropaganda and Political Warfare. Ed. by Michael J. W. Washington DC: Institute of World Politics Press, 2009), 74-83

Warsito, T., Kartikasari, W. (2007) Diplomasi Kebudayaan. Yogyakarta: Ombak

$\underline{\text { Journals }}$

Finn, H.K. (2003) 'The Case for Cultural Diplomacy: Engaging Foreign Audiences'. Foreign Affairs 82 (6), 15-20 
Griffin, M. (2009) 'Narrative, Culture and Diplomacy'. The Journal of Arts and Management, Law and Society 38 (4) 258-269

Jang, G., and Paik, K.W. (2012) 'Korean Wave as Tool for Korea's New Cultural Diplomacy'. Scientific Research 2 (3) 196-201

Ma, R.M. (2014) 'Cultural Diplomacy in Asean: Collaborative Efforts' International Journal of Social Science and Humanity 5 (4) 394-397

Memis, S. (2009) 'Fostering a Cultural Diplomacy Policy Dialogue: The Quest for Stewardship and Cooperative Engagement' The Journal of Arts, Management, Law and Societies 39 (4) 297-304

Monten, J. (2005) 'The Roots of the Bush Doctrine: Power, Nationalism, and Democracy Promotion in US Strategy' International Security 29 (4), 122

Schneider, C. P. (2006) 'Cultural diplomacy: Hard to define, but you'd know it if you saw it' Brown Journal of World affairs I (xiii) 191-203

Schneider, C. P. (2009) 'The unrealized Potential of Cultural Diplomacy: Best Practices and what could be, if only' The Journal of Arts and Management, Law and Society 39 (4), 260-276

Stamatoudi, I. (2009) 'Mediation and Cultural Diplomacy'. United Nations Educational Museum International 61 (2), 116-120

\section{Internet Sources}

Institute for Cultural Diplomacy. (2014) What is Cultural Diplomacy? What is Soft Power? [online] available from $<$ http://www.culturaldiplomacy.org/index.php?en culturaldiplomacy $>$ July 2014]

National University of Singapore. (2012) Cultural Diplomacy for the 21st Century [online] available from < http://www.youtube.com/watch?v=C4Qgq92bF0E $>$ [24 May 2014] 